to the front and to hospitals in the rear. During twelve months of war literally hundreds of tons of blood have been thus applied to wounded men in all stages of evacuation, and with truly tremendous success.

Narkomzdrav regularly sends out groups of experienced specialists-scientific collaborators from the institutes and stations-who give practical assistance in ensuring the adequate supply of conserved blood at the front. Thus, thanks to timely blood transfusion, we can indeed say that hundreds of thousands of human lives have been saved.

\section{The Plasma Method}

The most diverse methods of haemotherapy have been extensively used-the drip method of blood transfusion, the transfusion of plasma and serum, immunotransfusion, the injection of small doses of blood of incompatible groups, and iheterohaemotherapy. Among these the plasma method has a particularly wide scope in present wartime conditions. It is known that blood plasma is the main substratum of metabolism ; and its most striking feature is that, despite the constant inflow of matter and energy, its composition remains unaltered. Soviet scientists are in complete accord with the conclusions of British and American scientists that, as a medium impregnated with plastic substances and containing a large quantity of ferments exerting a haemostatic action on the organism, as well as a medium in which viscosity and osmotic pressure are almost at the same level as in whole blood, plasma beyond a doubt possesses unqualified advantages as a blood substitute.

With the object of establishing the most favourable conditions for preserving plasma over long periods we have had recourse to freezing it. As did M. Struma and S. M'Graw in their investigations, the Central Institute for Blood Transfusion has found that when plasma is frozen and afterwards quickly thawed at a temperature of $37^{\circ} \mathrm{C}$.-immediately preceding transfusion or a short while before-it preserves intact such labile elements as prothrombin, fibrinogen, and complement. Recently we have introduced into practice desiccated plasma and serum preparations. Under front-line conditions plasma finds wide scope as a highly active haemostatic agent in cases of protracted loss of blood in which the transfusion of massive doses of blood is contraindicated. As a substitute for blood, plasma is employed in cases of shock accompanied by a moderate blood loss, when the organism still retains an adequate reserve of erythrocytes. In cases of burns we have found plasma of great service. When introduced in large volume, following heavy loss of blood, it usually has a most striking detoxicating effect. We employ various balanced physiological solutions for preserving the erythrocyte mass remaining after the plasma has been separated." We have recently been using the following solution: $\mathrm{MgSO}_{4}, 0.04$ gr. $; \mathrm{KCl}, 0.2$ gr. ; NaCl, 8.5 gr. per litre of double-distilled water. It has been termed the modified I.P.K. fluid.* This fluid is mixed with the erythrocyte mass in different ratios. After the plasma has been separated from them and replaced with the modified I.P.K. fluid, the conserved blood erythrocytes are preserved in an external temperature of $4^{\circ}$ to $6^{\circ} \mathrm{C}$. Under these conditions they show no marked change up to 12 days, including the day the blood was taken from the donor. The transfusion of conserved blood erythrocytes containing this plasma substitute was found most effective in those cases of anaemia in which the aim of medical treatment is preferably to obtain a substitutive effect-that is, cases of much loss of blood, regenerative forms of posthaemorrhagic anaemia, etc. Naturally, the erythrocyte mass method is of service mainly in hospitals situated not far from the institute or station preparing these erythrocytes.

Plasma Substitutes. - The wide application of blood transfusion in the U.S.S.R. and the generous manner in which donors give blood for the needs of the Army and civil medical institutions have not relegated the question of blood substitutes, or, rather, plasma substitutes, that can be employed in all cases in which the main object is that of augmenting the volume of circulating blood. From our point of view, any physiological solution containing only salt ingredients, without colloids to maintain the viscosity and osmotic pressure of the solution on a level approaching that of plasma, is useless as such a

*I.P.K.--initial letters of the Russian for " Blood Transfusion Institute." substitute. Balanced solutions containing a small volume of blood or plasma have recently been finding a practical use as isotonic fluids with a natural colloid. Other solutions also serving this end are those in which the colloidal properties are ensured by adding casein that has been specially processed, with the object of eliminating the antigenic properties inherent in this preparation. The complicated circumstances existing in the front line sometimes preclude the possibility of utilizing conserved blood within its period of serviceability, and these are the conditions under which plasma, as well as synthesized substitutes for the latter, is of chief use. From a fairly wide experience we may draw the conclusion that in cases of acute loss of blood and shock, when infusion of plasma substitutes is carried out in conjunction with haemotherapy, a favourable influence on the condition of the patients' haemodynamics is usually obtained by the use of small doses of blood or plasma.

Side by side with colloidal substitutes for plasma we have recently introduced on a wide scale so-called physiological balanced solutions containing alcohol and glucose. These solutions, which mainly reinforce the vital processes, are administered in cases in which the wounded patient suffers from disturbed haemodynamics not associated with heavy blood loss, and also in septic cases.

It is no matter for surprise that since the outbreak of war a tremendous number of Soviet patriots have streamed into the numerous blood transfusion institutes and stations. From early morning till late at night these institutions seethe with activity. New donors undergo medical examination, their blood groups are checked, blood is taken and conserved, and jars and ampoules are packed for urgent dispatch to the front. And these donors are not only the donors-so to say, "cadre" donors-who used to give blood for transfusion before the war. They largely consist of the huge number of those who declared their desire to give blood for transfusion to the wounded when necessity arose. This great army is held in reserve, and at the very first 'call they flock to the transfusion centres to give their blood. And this reserve army has been augmented to-day by a great number of people in all walks of life. Even the briefest of informative talks on the important part which blood transfusion and the donor play in the Soviet army medical services suffices to bring to the institutes and stations groups of workers, students, militiamen, housewives, and the wives of those on active service, expressly to join the ranks of donors.

\section{COMMENTS ON AN EPIDEMIC OF HEPATITIS}

\author{
BY
}

\section{PHILIP EVANS, M.D., M.Sc., M.R.C.P.}

Assistant Physician for Children, King's College Hospital

The hospital in which the epidemic occurred was formed in Sept., 1939, and has catered for up to 120 children at a .time, as well as for a variable number of adults. The children have been nursed mainly by children's nurses in training, and these young women have been chiefly affected.

\section{History of the Outbreak}

In March, 1940, a nurse became jaundiced (Table I), and a second case occurred 35 days later. Shortly afterwards 2 nurses were transferred from another hospital, where the infection was rife, and they soon developed the illness. In August another nurse was affected, and in October another. Thus in 7 months 4 nurses probably acquired the disease in the hospital, and this epidemic period was followed by an outbreak in one ward affecting in a month 5 children and 5 nurses who worked in that ward, while 2 nurses and a wardmaid were probably infected in the nurses' sick-rooms. The outbreak later declined, but during the final 17 months' observation a further 8 children and 30 nurses became jaundiced. Ten children who had acquired the disease elsewhere were also admitted during this time. 
Table I shows the ramifications of the epidemic. From its study certain features may be picked out for comment.

TABLE I.-Cases of Infectious Jaundice in Hospital between Oct., 1939, and June, 1942

\begin{tabular}{|c|c|c|c|c|c|c|c|}
\hline No. & $\begin{array}{l}\text { Nurse } \\
\text { or } \\
\text { Child }\end{array}$ & $\begin{array}{c}\text { Where } \\
\text { Probably } \\
\text { Infected }\end{array}$ & $\begin{array}{l}\text { Where } \\
\text { at } \\
\text { Onset }\end{array}$ & $\begin{array}{c}\text { Where } \\
\text { Nursed } \\
\text { when } \\
\text { IIl }\end{array}$ & $\begin{array}{l}\text { Date of } \\
\text { Onset }\end{array}$ & $\begin{array}{c}\text { Date of } \\
\text { Jaundice }\end{array}$ & Remarks \\
\hline 1 & Nurse & & C2 & N.S.R. & $21 / 3 / 40$ & $25 / 3 / 40$ & \multirow{28}{*}{$\begin{array}{c}\text { Admitted } \\
24 / 1 / 41\end{array}$} \\
\hline$\frac{2}{3}$ & $"$ & $\begin{array}{l}\text { C2 } \\
\text { Away }\end{array}$ & $\begin{array}{l}\mathrm{C1} \\
\mathrm{C4}\end{array}$ & $\begin{array}{l}\text { N.S.R. } \\
\text { N.S.R. }\end{array}$ & $\begin{array}{r}25 / 4 / 40 \\
6 / 5 / 40\end{array}$ & $29 / 4 / 40$ & \\
\hline 4 & ", & $\begin{array}{l}\text { Away } \\
\text { Away }\end{array}$ & $\mathrm{C} 1$ & N.S.R. & $\begin{array}{l}0 / 7 / 40 \\
16 / 5 / 40\end{array}$ & & \\
\hline 5 & $"$ & $\stackrel{?}{?}$ & $\mathrm{C} 3$ & N.S.R. & $\begin{array}{l}19 / 8 / 40 \\
\end{array}$ & 19/9/40 & \\
\hline $\mathbf{0}$ & Child & $\begin{array}{l}\text { C3 } \\
\text { C4 }\end{array}$ & $\begin{array}{l}\text { C3 } \\
\text { C4 }\end{array}$ & $\begin{array}{l}\text { N.S.R. } \\
\text {.C4 }\end{array}$ & $\begin{array}{l}22 / 10 / 40 \\
18 / 12 / 40\end{array}$ & $\begin{array}{l}24 / 10 / 40 \\
27 / 12 / 40\end{array}$ & \\
\hline & N"יקce & $\mathrm{C4}$ & C4 & $\mathrm{CH}_{\mathrm{P}}$ & $20 / 12 / 40$ & $22 / 12 / 40$ & \\
\hline 10 & Nurse & $\mathrm{C4}$ & C3 & $\begin{array}{l}\text { N.S.R. } \\
\text { Away }\end{array}$ & $\begin{array}{l}28 / 12 / 40 \\
29 / 12 / 40\end{array}$ & $\begin{array}{r}2 / 1 / 41 \\
29 / 12 / 40\end{array}$ & \\
\hline 11 & Child & $\begin{array}{l}\text { C4 } \\
\text { C4 }\end{array}$ & $\begin{array}{l}\mathrm{C} 4 \\
\mathrm{C}\end{array}$ & N.S.R. & $30 / 12 / 40$ & $\begin{array}{r}8 / 1 / 41 \\
12 / 141\end{array}$ & \\
\hline 13 & Nurse & C4 & $\mathrm{CH}$ & N.S.R. & $8 / 1 / 41$ & $8 / 1 / 41$ & \\
\hline $\begin{array}{l}14 \\
15\end{array}$ & $\begin{array}{l}\text { Child } \\
\text { Ward }\end{array}$ & $\begin{array}{l}\text { C4 } \\
\text { N.S.R. }\end{array}$ & & $\begin{array}{c}\text { C4 } \\
\text { Away }\end{array}$ & $\begin{array}{l}8 / 1 / 41 \\
9 / 1 / 41\end{array}$ & $\begin{array}{r}12 / 1 / 41 \\
9 / 1 / 41\end{array}$ & \\
\hline 16 & $\begin{array}{l}\text { maid } \\
\text { Nurse }\end{array}$ & N.S.R. & Away & Away & $11 / 1 / 41$ & \multirow{4}{*}{$20 / 1 / 41$} & \\
\hline 17 & $"$ & $C 4$ & Away & Away & $11 / 1 / 41$ & & \\
\hline $\begin{array}{l}18 \\
19\end{array}$ & Child & N.S.R. & Away & Away. & $\begin{array}{l}12 / 1 / 41 \\
16 / 141\end{array}$ & & \\
\hline & Nurse & N.S.R. & Away & Away & $20 / 1 / 41$ & & \\
\hline 21 & & ? M. & Away & Away & $24 / 1 / 41$ & \multirow[t]{2}{*}{$30 / 1 / 41$} & \\
\hline 22 & Child & Away & Away & $\mathrm{C} 4$ & $10 / 1 / 41$ & & \\
\hline $\begin{array}{l}23 \\
24\end{array}$ & Nurse & C4 & C1 & Away & $2 / 2 / 41$ & \multirow{11}{*}{$\begin{array}{r}25 / 3 / 41 \\
2 / 4 / 41 \\
2 / 5 / 41 \\
6 / 5 / 41 \\
4 / 5 / 41 \\
5 / 5 / 41 \\
6 / 5 / 41 \\
2 / 6 / 41 \\
30 / 5 / 41 \\
7 / 6 / 41 \\
13 / 6 / 41 \\
13 / 6 / 41 \\
14 / 6 / 1 \\
17 / 6 / 41\end{array}$} & \\
\hline $\begin{array}{l}24 \\
25\end{array}$ & $"$ & $\begin{array}{l}\mathrm{C} 3 \\
\mathrm{C} 4\end{array}$ & $\begin{array}{l}\text { C5 } \\
\text { C4 }\end{array}$ & $\begin{array}{l}\text { N.S.R. } \\
\text { N.S.R. }\end{array}$ & $\begin{array}{l}17 / 3 / 41 \\
26 / 3 / 41\end{array}$ & & \\
\hline 26 & Child & C5 & C5 & C5 & $26 / 4 / 41$ & & \\
\hline & Nüree & C5 & C5 & C5 & $1 / 5 / 41$ & & \\
\hline 29 & Child & C5 & C5 & Away & $\begin{array}{l}3 / 5 / 41 \\
4 / 5 / 41\end{array}$ & & \\
\hline 30 & Nürse & C5 & C5 & C5 & 6/5/41 & & \\
\hline 32 & " & C3 & $\begin{array}{l}\text { Away } \\
\text { C4 }\end{array}$ & $\begin{array}{l}\text { Away } \\
\text { Away }\end{array}$ & $\begin{array}{l}26 / 5 / 41 \\
30 / 5 / 41\end{array}$ & & \\
\hline $\begin{array}{l}33 \\
34\end{array}$ & $"$ & C3 & $\begin{array}{c}\mathrm{C} 4, \mathrm{Cl} \\
\mathrm{C3}\end{array}$ & N.S.R. & $\begin{array}{l}4 / 6 / 41 \\
8 / 6 / 41\end{array}$ & & \\
\hline 35 & $"$ & C 3 & C3 & N.S.R. & $10 / 6 / 41$ & & \\
\hline 36 & " & C3 & C3 & $\mathrm{C3}$ & & & \\
\hline 38 & Siš̈er & $\begin{array}{l}\text { C3 } \\
\text { N.S.R. }\end{array}$ & $\begin{array}{l}\text { C3 } \\
\text { Away }\end{array}$ & $\begin{array}{l}\text { N.S.R. } \\
\text { Away }\end{array}$ & $\begin{array}{r}17 / 6 / 41 \\
7 / 7 / 41\end{array}$ & & \\
\hline & Child & Away & Away & $\mathrm{C} 4$ & $20 / 7 / 41$ & $21 / 7 / 41$ & \\
\hline 40 & M'seuse & $\stackrel{?}{?}$ & $?$ & N.S.R. & $23 / 7 / 41$ & \multirow[t]{2}{*}{$28 / 7 / 41$} & \\
\hline 41 & Nurse & $\begin{array}{l}\text { N.S.R., } \\
\text { C4, or }\end{array}$ & A1 & N.S.R. & & & $\begin{array}{l}\text { N.S.R.8-28/5/41 } \\
\text { C4 } 3 / 6-3 / 7 / 41\end{array}$ \\
\hline $\begin{array}{l}42 \\
43\end{array}$ & " & ? & C4 & Away & $2 / 8 / 41$ & $5 / 8 / 41$ & \\
\hline 43 & Child & C4 & Away & Away & $? 11 / 8 / 41$ & \multirow{2}{*}{$21 / 8 / 41$} & \\
\hline & & & Away & $\mathrm{C} 3$ & $21 / 8 / 41$ & & $\begin{array}{l}\text { Admitted } \\
27 / 8 / 41\end{array}$ \\
\hline 45 & ", & Away & Away & $\mathrm{C} 2$ & $25 / 8 / 41$ & $26 / 8 / 41$ & Admitted \\
\hline 46 & $"$ & $\mathrm{C4}$ & C4 & C4 & $1 / 9 / 41$ & \multirow{2}{*}{$\begin{array}{r}4 / 9 / 41 \\
12 / 9 / 41\end{array}$} & \\
\hline & , & ? Away & C4 & C4 & 7/9/41 & & Admitted \\
\hline $\begin{array}{l}48 \\
49\end{array}$ & $\begin{array}{l}\text { Nurse } \\
\text { Child }\end{array}$ & $\begin{array}{l}\text { C4 } \\
\text { Away }\end{array}$ & $\begin{array}{l}\text { C2 } \\
\text { Away }\end{array}$ & $\underset{\text { C3 }}{\text { N.S.R. }}$ & 11/9/41 & $12 / 9 / 41$ & Admit \\
\hline 50 & " & Away & Away & C2 & $?$ & & $\begin{array}{c}16 / 9 / 41 \\
\text { Admitted }\end{array}$ \\
\hline 51 & Nurse & N.S.R. & C3 & NSSR. & $18 / 9 / 41$ & \multirow{6}{*}{$\begin{array}{r}30 / 9 / 41 \\
29 / 9 / 41 \\
29 / 10 / 41 \\
19 / 12 / 41 \\
20 / 12441 \\
18 / 1 / 42 \\
13 / 3 / 42\end{array}$} & $\begin{array}{c}16 / 9 / 41 \\
\text { Nured Case } 41\end{array}$ \\
\hline 52 & Child & C4 & C4 & $\mathrm{C4}$ & $23 / 9 / 41$ & & \\
\hline $\begin{array}{l}53 \\
54\end{array}$ & $\begin{array}{l}\text { Nurse } \\
\text { Chidd }\end{array}$ & C3 & C3 & N.S.R. & $26 / 9 / 41$ & & \\
\hline 55 & Nurse & C4 & N.S.R. & $\begin{array}{l}\text { C4 } \\
\text { Away }\end{array}$ & $\begin{array}{l}29 / 10 / 41 \\
14 / 12 / 41\end{array}$ & & \\
\hline & $"$ & $\mathrm{CS}_{\mathrm{S}}^{\mathrm{C} 3}$ & $\mathrm{C3}$ & N.S.R. & $15 / 12 / 41$ & & \\
\hline (58 & $"$ & ?. C5. & $\stackrel{\text { M. }}{\mathrm{C} 5}$ & A. & $\begin{array}{l}18 / 1 / 42 \\
? 8 / 3 / 42\end{array}$ & & \\
\hline 59 & Child & & $C_{2}$ & C? & $?$ & & \\
\hline & Cina & Away & $c 2$ & $\mathrm{C}_{2}$ & $?$ & $10 / 3 / 42$ & $\begin{array}{l}\text { Admitted } \\
24 / 2 / 42\end{array}$ \\
\hline 60 & $\begin{array}{l}\text { Nurse } \\
\text { Child }\end{array}$ & $\begin{array}{l}\text { ? C5 } \\
\text { Away }\end{array}$ & $\begin{array}{l}\text { C5 } \\
\text { C2 }\end{array}$ & A6 & $4 / 5 / 42$ & \multirow{2}{*}{$\begin{array}{r}6 / 5 / 42 \\
28 / 3 / 42\end{array}$} & \\
\hline & Nurce & & & & & & $18 / 2 / 42$ \\
\hline 63 & & ? A6 & $\mathrm{C4}$ & A6 & $4 / 5 / 42$ & $\begin{array}{r}18 / 4 / 42 \\
6 / 5 / 42\end{array}$ & C4 $17 / 2-17 / 4 / 42$. \\
\hline 4 & & & & & & \multirow{2}{*}{$18 / 5 / 42$} & and from $17 / 4 / 42$ \\
\hline & Nurse & C4 & Away & Away & $4 / 6 / 42$ & & \\
\hline
\end{tabular}

$\mathrm{C1}, \mathrm{C2}, \mathrm{C} 3, \mathrm{C4}$, and $\mathrm{C} 5$ are children's wards. M. is the maternity ward. A1 and A6 are adult medical wards. N.S.R. means nurses' sick-rooms (attached to C3). "Away" means outside the hospital.

The endemic stage, in which single cases appeared at intervals of 1,2 , and 3 months, shows that infection was smouldering in the hospital for some time before conditions were ripe for an epidemic. It suggests, too, that the incubation period varies widely and may be longer than 3 months, that there are carriers, or that subclinical infection may occur.

Subclinical infection here means infection without jaundice, but not necessarily without symptoms. No proof of the existence of such infection was found, but several observations suggest that it does exist. No direct source of the outbreak in ward C4 was discovered, but a nurse in that ward had an attack of frequent vomiting, without pyrexia, diarrhoea, or jaundice, on Dec. 1 and 2. She was admitted to a nurses' sickroom (attached to C3 ward). Jaundice followed in patients in C4 from Dec. 22 onwards, and in the sick-room attendants from Jan. 9.

Late in 1941 another nurse was in C4 when a boy developed jaundice for one day (Oct. 29). The nurse had an attack of severe vomiting for which she was " warded" from Nov. 21 to 28 ; she was nursed by patient No. 56, who was not in contact with any known patient with jaundice but who developed the disease on Dec. 15.

Young children usually have mild attacks, often consisting only of a pale stool or two, faint jaundice, bile in the urine for a day or so, and a rise of temperature to $99^{\circ}-100^{\circ}$. It is easy to imagine yet milder attacks in which jaundice is not noticeable. For instance, a boy aged 2 in ward C5 seemed out of sorts and lost his appetite for one day. He passed one pale stool, but had no jaundice of conjunctiva or urine, and the occurrence would have attracted little notice if 4 children and a nurse had not developed hepatitis in that ward during the preceding 11 days. No one who reads Newman's (1942) persuasive paper is likely to doubt the existence of abortive cases. Cullinan (1939) has described a patient seen by A. W. Franklin who had biliuria in the morning but not in the afternoon. Case 54 had only a trace of jaundice of the conjunctiva, and had biliuria for one day.

\section{Incidence of Hepatitis}

That age affects the development of hepatitis even in children is a clinical impression: children from 1 to 4 years old seem to have brief mild attacks with slight jaundice, and often negligible prodromata. Table II bears out the contention that

TABLE II.-Age of Children admitted to Hospital, and Number getting Jaundice, between April 25, 1940, and May 31, 1942

\begin{tabular}{|c|c|c|}
\hline Age in Years & No. of Admissions & No. with Jaundice \\
\hline $\begin{array}{r}0 \\
1 \\
2 \\
3 \\
4 \\
5 \\
6 \\
7 \\
7 \\
8 \\
9 \\
10 \\
11 \\
12 \\
13 \\
14\end{array}$ & $\left.\begin{array}{r}243 \\
181 \\
150 \\
158 \\
189 \\
152 \\
133 \\
118 \\
93 \\
118 \\
98 \\
94 \\
76 \\
76 \\
22\end{array}\right\} 921$ & $\left.\begin{array}{l}0 \\
1 \\
0 \\
0 \\
1 \\
2 \\
1 \\
3 \\
1 \\
0 \\
1 \\
1 \\
2 \\
0 \\
0\end{array}\right\} 11$ \\
\hline
\end{tabular}

young children are relatively insusceptible. Babies are almost immune, though instances have been recorded' (Cockayne, 1912-13). It is notable, too, that junior nurses were more likely to acquire the infection than senior: many of the latter had already had attacks. The regulations which permit, and thus ensure, that girls training as sick children's nurses shall be younger than those doing general training are partly responsible for the prevalence of infectious fevers in children's hospitals.

Studies of the seasonal incidence (cf.' Wallgren, 1930) show infectious hepatitis to be chiefly a disease of autumn and winter, though there are many exceptions. In the present

TABLE III.-Quarterly Incidence of Cases of Jaundice developing in Hospital

\begin{tabular}{c|c|c}
\hline Year & Quarter & No. of Cases \\
\hline 1940 & 1st & 1 \\
& 2nd & 1 \\
3rd & 6 \\
\hline 1941 & 4th & 13 \\
& 1st & 12 \\
& 2nd & 10 \\
\hline 1942 & 3rd & 2 \\
& 1st & 5 \\
\hline
\end{tabular}

outbreak the epidemic wave developed in the winter and spring of 1940-1, but there was no second wave the following winter (Table III). The ventilation of the blacked-out wards at night 
was better in the second than in the first winter, but this is probably irrelevant, for day and night nurses were affected in proportion to their numbers.

\section{The Incubation Period}

The incubation period has been variously estimated. Glover and Wilson (1931) and Glover (1939) considered that the abrupt character of the outbreak they studied suggested a short incubation period, probablv of 3 to 4 days. The majority of recent authors favour a longer period, and the conclusions of Glover and Wilson have been criticized by Pickles (1939b). Booth (1928) put it at 20 to 40 days, Pickles (1939a) at 23 to 35 days in three outbreaks. Most calculations have been based on case-to-case intervals, and there are few records of single exposures. Booth (1928) records one which indicates an incubation period of 31 days. Newman (1942) had instances of 29, 30, and 31 days. In one of Bashford's (1934) adult patients the period was apparently only 8 to 10 days. Wallgren (1930) observed hepatitis $15,21,20$ to 22,22 to 25 , 25 to 28,23 to 29,8 to 15 , and 31 to 40 days after exposure. Pickles (1939b) has good examples of 27, 27, 28, 28, 29, 31, and 34 days.

A few observations were made in the present outbreak. Case 24 was "warded" on March 17 and became iaundiced 8 days later. Children in her ward developed the disease 40 , 45,48 , and 50 days after the last contact with her, and another nurse in the ward developed hepatitis after 47 days. These are long periods, but no trace of an intermediate infection could be found, and to postulate one would merely substitute two unusually short periods for one unusually long one. Case 48 was exposed to infection 53 to 40 days before becoming ill, and not at any other time so far as was known. Case 57 was ill and was nursed by Case 56 (who developed hepatitis on Dec. 15) from Dec. 8 to 14 , and developed jaundice on Jan. 18, an interval of 35 to 41 days. In Cases 2, 46, and 47 incubation took more than 34,29 , and 35 days respectively ; in Case 53 less than 35 days; in Case 38 it was probably exactly 38 days.

It seems that infection usually takes about a month, but that longer or shorter periods are possible. The size of the infecting dose may well be important, as in enteric fever. There may also be differences between strains of the unidentified hepatotoxic agent; perhaps different routes of infection may also produce different incubation periods. Propert (1938) observed that jaundice developed 78 to 83 days after the injection of human serum which was probably contaminated with a virus causing hepatitis, and two contacts of the original patients developed jaundice two months later. This batch of serum produced cases elsewhere (MacNalty, 1938; Findlay, 1940). According to Findlay (1940), yellow fever vaccine, similarly contaminated, produced jaundice 2 to 3 months after injection.

\section{Duration and Degree of Infectivity}

The duration of infectivity is thought by Pickles (1939a, $1939 \mathrm{~b}$ ) to be short, chiefly because not all the susceptible members in a family epidemic develop jaundice in one batch after exposure, but instead become ill in succession at intervals of about a month. This curious sequence has been equally plausibly explained by Newman (1942), who postulates a phasic or intermittent susceptibility to the infection. Pickles has actually noted transmission 8 days before the development of symptoms, and on the fifth and seventh days of the disease. Bates (1936) suggested that infection could still be transmitted a month after jaundice appeared; but this is not a common experience, and other explanations of his observation are possible. The epidemic described here did not provide information about the limits of the infectious period, although it was clear that infection might be transmitted some time before jaundice showed-e.g., Case 24 infected 5 people on or before March 17, when she became ill, although she was not jaundiced until March 25.

The degree of infectivity is difficult to estimate, but a rough idea may be obtained from Table IV, in which the number of times a patient or a nurse developed an acute infectious fever in an apparently uninfected ward is compared with the number of times a secondary case followed the occurrence. It will be seen that in this computation (which does not include children admitted to hospital after jaundice had appeared or abortive cases) infectious jaundice occupies a middle position between the more and the less infectious fevers.

TABLE IV.-Number of Times a Secondary Case followed the Development of an Infectious Disease in Four Similar Children's Wards

\begin{tabular}{|c|c|c|c|c|}
\hline Disease & & $\begin{array}{l}\text { No. of Times } \\
\text { Infection } \\
\text { introduced (A) }\end{array}$ & $\begin{array}{l}\text { No. of Times } \\
\text { a Secondary Case } \\
\text { followed (B) }\end{array}$ & $\begin{array}{c}\text { Index of } \\
\text { Infectivity } \\
\text { (B/A) }\end{array}$ \\
\hline $\begin{array}{l}\text { Chicken-pox } \\
\text { German measles } \\
\text { Mumps } \\
\text { Infectious jaundice } \\
\text { Whooping-cough } \\
\text { Scarlet fever }\end{array}$ & $\begin{array}{l}\cdots \\
\cdots \\
\cdots \\
\cdots\end{array}$ & $\begin{array}{r}10 \\
6 \\
5 \\
11 \\
12 \\
11\end{array}$ & $\begin{array}{l}9 \\
5 \\
3 \\
6 \\
5 \\
1\end{array}$ & $\begin{array}{l}0.9 \\
0.8 \\
0.6 \\
0.6 \\
0.4 \\
0.1\end{array}$ \\
\hline
\end{tabular}

Pharyngitis without rash following scarlet fever and abortive hepatitis are not ncluded.

\section{Transmission of Infection}

The mode of transmission of infection in this epidemic, as in most, appeared to be aerial, and perhaps also by contagion. The frequency with which nurses became infected by nursing patients is striking when compared with the rarity with which patients in bed infected other patients, and suggests the possibility of the acquisition of the virus from faeces or urine. This is certainly not the usual route, for patients may infect one another by close proximity in out-patient waiting-rooms (Graham, 1938 ; Cullinan, 1939 ; Barber, 1937). A head master infected some pupils by merely walking through the rooms they were in (Newman, 1942); a rent collector visited infected houses and was himself stricken (Nicol, 1942). In one curious case (No. 38 in Table I) a sister spent a day in the next room to a nurse who had just developed jaundice, and came down with it herself 38 days later. There was no cirect communication between the rooms, but the two doors opened side by side into a common corridor, and the two patients were nursed by the same staff. Apparently contact need not be very close, although it undoubtedly usually is. Wider spacing in a hospital waiting-room has been followed by the ending of an outbreak (Barber, 1937).

Usually a direct communication can be traced from case to case, while at times an abortive case seems to be the cause. I doubt if healthy carriers played much (or any) part in this epidemic, although their existence has been suggested by Cockayne (1912-13) and Newman (1942).

\section{Some Further Points}

Relapse is uncommon, but has been recorded (Cockayne, 1912-13 ; Bates, 1936; Newman, 1942): I have seen it once in a man aged 53. Second attacks are rare, but are mentioned by Findlay, Dunlop, and Brown (1931) and Newman (1942). Convalescence is long. Many non-medical people do not think "the yellow jaundice" is catching, nor do they realize that

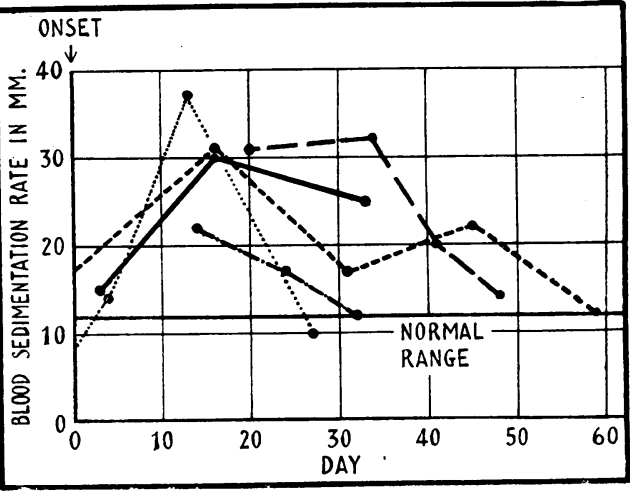

Chart showing the blood sedimentation rate (Payne's method) in 5 children who had mild attacks.

it may make a patient feel ill and exhausted for weeks. It is often treated as an "ambulant illness," but it is in fact an important cause of loss of health: few nurses at this hospital were well enough to work in as short a time as a month. Blood sedimentation rates may remain elevated for several weeks (see Chart). 
Finally, the role of a children's hospital as a reservoir of infection is obvious. There is a long incubation period, and many nurses happened to be on holiday when they became ill, and thus carried infection into parts of Berkshire, Hampshire, Kent, Lancashire, Middlesex, Oxfordshire, Staffordshire, and Sussex. There seems no reason why the thread of infection should die out of the hospital while it exists in its present form, for its population is continually being refreshed by the influx of susceptible children and young nurses. If this should not be enough, another outbreak could be started by the admission of a patient incubating the disease-a fairly common event.

\section{Summary}

Infectious hepatitis became endemic in a hospital early in 1940, and in the following winter an epidemic started. It gradually subsided in the next year and a half, but the frequent introduction of young nurses and children into the community is likely to maintain the infection and form a reservoir from which the disease can be distributed to other places.

Infection is usually transmitted from case to case, but abortive cases are probably important links in the chain of infection.

Young children and senior nurses are less susceptible than older children and junior nurses.

The incubation period is usually about a month, but shorter and considerably longer periods are possible. The duration of infectivity is uncertain. Hepatitis is easily transmitted, but is probably less infectious than varicella or rubella.

The disease often produces several weeks of invalidism. The blood sedimentation rate may remain elevated for some weeks after a mild attack.

\section{REFERENCES}

Barber, H. (1937). British Medical Journal, 1, 67

Bashford, $H$.

Bates, R. (1936). British Medical Journal, 1, 521

Booth, W. G. (1928). Publ. Hlth., 41, 237.

Cockayne, E. A. (1912-13). Quart. J. Med., 6, 1.

Cullinan, E. R. (1939). Proc. roy. Soc. Med., 32, 933.

Findlay, G. M. (1940). J. R.A.M.C., 74, 72

25, 7 .

Glover, J. A. (1939). Proc. roy. Soc. Med., 32, 946.

and Wilson, J. (1931). Lancet, 1, 722.

MacNalty; A. S. (1938). Ann. Rep. Chief Med. Off. Min. of Health for 1937, p. 38, London

Newman, J. L. (1942). British Medical Journal, 1, 61

Nicol, C. G. (1942). ibid., 1, 466

Nicol, C. G. (1942). Ibid., 1, 466.

- (1939b). Epidemiology in Country Practice, p. 59, Bristol and London

Propert, S. A. (1938). British Medical Journal, 2, 677.

Wallgren, A. (1930). Acta paediat., 9, Supp. 2, 32.

\section{IN-PATIENT TREATMENT OF CIVILIAN NEUROTIC CASUALTIES}

\section{REPORT ON 100 CASES TREATED IN AN E.M.S. NEUROSIS CENTRE}

\author{
BY
}

W. S. MACLAY, M.D., M.R.C.P., D.P.M.

Medical Superintendent, Mill Hill Emergency Hospital AND

\section{J. WHITBY, M.D., M.R.C.P., D.P.M.} Psychiatrist at Mill Hill Emergency Hospital

The Emergency Medical Service is responsible for the care of civilian casualties. As a result of enemy action, particularly after the severe air raids in the autumn of 1940 , some of the neurotic cases continued for a prolonged period to be unfit for work, and it was decided that specialized investigation was required to determine whether their condition was in fact due to "war injury" and whether they could be benefited by in-patient treatment at a neurosis hospital. Cases of long standing were therefore seen by a psychiatrist, and those suitable were offered in-patient treatment.

This paper is based on a study of the first hundred patients who passed through the hospital between July, 1941, when the scheme came into operation, and January, 1942. The total number referred was very little more, and as this hospital serves a large area, including London, there would appear to have been but few neurotic casualties in the country at that time. The paper is not intended to be a statistical one, but to point to factors of interest in the aetiology of the illness, and to the results of treatment.

The material investigated consisted of 70 men (of whom 20 came from Services such as Fire, Police, or Merchant Navy, the remainder being civilians) and 30 women, none of whom were in these Services. Their average age was 45 years, which is significantly higher than the average age of the usual patients attending practitioners at this period, and indicates that the special stresses fell more heavily on the older age groups. All had been closely exposed to bombing, which constituted the precipitating factor and which was followed by incapacity for work. They- may therefore be considered in chronological periods before and after this incident.

\section{Before the Incident}

Family history may be disregarded, as, although information concerning neurosis or psychosis in close relatives was inquired for, a positive history was rarely obtained. Significant physical illness occurred in 11 instances. Among these were physical disorders such as cerebral arteriosclerosis and Parkinsonism now masquerading as neurotic illnesses. Other physical disorders, although contributing to the total picture, did not affect the prognosis of the neurosis. Definite neurotic illness had occurred in 13 patients and psychosis in 3 . These figures are high for the general population but low for neurosis cases in pre-war praçtice, and would indicate that many, but not all, of the illnesses arose in people who do not easily break down. The diagnosis of the previous illness was not necessarily the same as the present one, hysteria being the only condition that recurred relatively often.

Personality characteristics of a kind which are usually regarded as predisposing to illness, such as " timid," " nervous," " worrying," "irritable," or " obsessional," and which were sufficiently marked to be apparent, occurred in 24 . They coloured the content and contributed to the total picture of the illness, but they were not correlated with the diagnosis, and bore no relation to the outcome of the illness. Although it may be argued that predisposition could have been found in $100 \%$ if enough trouble had been taken, the fact remains that by ordinary standards a large proportion of these patients had had a good previous personality. This is one reason why the results of treatment were good. These cases are not comparable to the compensation neuroses of peacetime or to the soldiers who are unable to adapt to Army training; rather should they be compared to soldiers of good personality who broke down after such exceptional stress as Dunkirk and who tended to make a quick recovery in hospital. That a large number had stable personalities is confirmed by the fact that $90 \%$ of the men had steady work recordis, unlike the work histories so often oblained ameng peacetime neurotics.

In the period immediately preceding the incident 30 cases had been subjected to prolonged stress, beyond that of the average civilian, bv virtue of their special occupations, including those in the Fire, Police, and A.R.P. services or in the Merchant Navy. Of these, 19 had begun to show symptoms but had not been off work. Nevertheless in these cases the results of treatment as regards symptoms were no different from the others.

\section{The Precipitating Incident}

The comparison with the Dunkirk cases is apt in that our patients were not those who broke down through a bomb merely dropping somewhere in the neighbourhood. On the contrary, 86 as a result of bombing had endured severe mental stress, such as loss of husband, wife, or children, loss of home or business, or being buried for hours. The severity of the incident is borne out by the fact that 50 sustained physical injury also, excluding minor bruising. It is interesting to note that among soldiers in the last war neurotic illness rarely coexisted with physical injury. Presumably anxiety in a soldier is relieved by a wound which will remove him from the battle area; but this does not happen to the bombed civilian, and other factors become more important.

Another common finding in these patients was that the majority had previously heard bombs exploding in the vicinity 